\title{
Medical Students' Perception of Their Education and Training to Cope with Future Market Trends [Retraction]
}

Iesa MAM. Adv Med Educ Pract. 2020;11:237-243.

The Editor-in-Chief and Publisher of Advances in Medical Education and Practices wish to retract the published article.

We were notified of potential discrepancies between three articles cited in the Background Studies section of the published article. The cited articles do not appear related to the data they were being used to describe. The studies cited were listed as references 19, 20 and 21:

- Lunt N, Horsfall D, Smith R, Exworthy M, Hanefeld J, Mannion R. Market size, market share and market strategy: three myths of medical tourism. Policy Politics. 2014;42(4):597-614. https://doi.org/10. 1332/030557312X655918

- Lempp H, Seale C. The hidden curriculum in undergraduate medical education: qualitative study of medical students' perceptions of teaching. BMJ. 2004;329(7469):770-773. https://doi.org/10.1136/ bmj.329.7469.770

- Könings KD, Brand-Gruwel S, Van Merriënboer JJ. Towards more powerful learning environments through combining the perspectives of designers, teachers, and students. Br J Educ Psychol. 2005;75(4):645-660. https://doi.org/10.1348/ $\underline{000709905 X 43616}$
The data being referred to by these references appears to have come from another study which was not cited:

- Rouhani MJ, Burleigh EJ, Hobbis C, Dunford C, Osman NI, Gan C, Gibbons NB, Ahmed HU, Miah S. UK medical students' perceptions, attitudes, and interest toward medical leadership and clinician managers. Adv Med Educ Pract. 2018;9:119-124. https:// doi.org/10.2147/AMEP.S151436

The author was contacted but was unable to provide a satisfactory explanation for the alleged discrepancies. The author was also unable to provide satisfactory raw data for their study and could not provide details of the questionnaires used for the survey or details of the UK medical schools or students described in their study. The editor determined the findings of the study were no longer valid and requested for the article to be retracted.

Our decision-making was informed by our policy on publishing ethics and integrity and the COPE guidelines on retraction.

The retracted article will remain online to maintain the scholarly record, but it will be digitally watermarked on each page as "Retracted". reviewed, open access journal that aims to present and publish research on Medical Education covering medical, dental, nursing and allied health care professional education. The journal covers undergraduate education, postgraduate training and continuing medical education

including emerging trends and innovative models linking education, research, and health care services. The manuscript management system is completely online and includes a very quick and fair peer-review system. Visit http://www.dovepress.com/testimonials.php to read real quotes from published authors. 